Article

\title{
Impact of Perceived Organizational Support on OCB in the Time of COVID-19 Pandemic in Hungary: Employee Engagement and Affective Commitment as Mediators
}

\author{
Ayman Alshaabani ${ }^{1, *} \mathbb{D}$, Farheen $\mathrm{Naz}^{1}$, Róbert Magda ${ }^{1,2}$ 迥 and Ildikó Rudnák ${ }^{1}$ \\ 1 Institute of Economics, Hungarian University of Agriculture and Life Sciences, 2100 Gödöllo, Hungary; \\ ask2farheen@gmail.com (F.N.); Magda.Robert@uni-mate.hu (R.M.); Rudnak.Ildiko@uni-mate.hu (I.R.) \\ 2 Vanderbijlpark Campus, North-West University, Vanderbijlpark 1900, South Africa \\ * Correspondence: a.shaabany@gmail.com; Tel.: +36-70-613-0097
}

\section{check for} updates

Citation: Alshaabani, A.; Naz, F.; Magda, R.; Rudnák, I. Impact of Perceived Organizational Support on OCB in the Time of COVID-19

Pandemic in Hungary: Employee

Engagement and Affective

Commitment as Mediators.

Sustainability 2021, 13, 7800

https://doi.org10.3390/su13147800/

Academic Editor: Alexandre

Garcia-Mas

Received: 13 June 2021

Accepted: 7 July 2021

Published: 13 July 2021

Publisher's Note: MDPI stays neutral with regard to jurisdictional claims in published maps and institutional affiliations.

Copyright: (c) 2021 by the authors. Licensee MDPI, Basel, Switzerland. This article is an open access article distributed under the terms and conditions of the Creative Commons Attribution (CC BY) license (https:// creativecommons.org/licenses/by/ $4.0 /)$.

\begin{abstract}
The performance of the employees and productivity of each individual, in general, have been badly affected because of the COVID-19 pandemic. Organizational citizenship behavior is regarded as an interpretation of the performance of the employee which is essential to contribute more to the organization's processes and success. Therefore, to increase the organizational effectiveness and achieve its goals, it is crucial to understand the factors affecting the organizational citizenship behavior of the employees. This study aims to examine the impact of perceived organizational support on organizational citizenship behavior with the mediating role of employee engagement and affective commitment. To collect the data for this study, a linear snowball sampling method was used, and 380 foreign employees working in different service companies in Hungary participated in the survey. Structural equation modeling (SEM) was used to test the proposed hypothesis. The results of the study revealed that perceived organizational support positively associated with organizational citizenship behavior and this relationship is also strongly mediated by employee engagement. On the other hand, employee engagement and affective commitment pose a direct positive influence on organizational citizenship behavior. This study has theoretical and practical implications as it will provide a comprehensive framework to better understand the factors influencing the organizational citizenship behavior of the employees.
\end{abstract}

Keywords: perceived organizational support; OCB; employee engagement; affective commitment; COVID-19

\section{Introduction}

The emergence and spread of coronavirus (COVID-19) around the globe has posed a great danger to the health and lives of human beings [1]. The COVID-19 pandemic has badly affected human life as well as businesses. It not only disrupted the daily life of the individual but also the function of an organization or workplace [2]. The pandemic has caused severe stress worldwide which is not controllable in comparison to stress experience by an individual in daily life [3,4], and it caused extreme harms to businesses, countries, and individuals at distinct levels [1]. The harmful impact of the COVID-19 pandemic on businesses requires a drastic change in the HR policies, behaviors of the management, and employee performance to remain competitive during the pandemic [5]. Furthermore, organizations need to adjust themselves rapidly to a dynamic environment to achieve competitiveness and success [6].

The COVID-19 outbreak has severely affected both the private and public sectors. It has disrupted operations in many sectors in a country such as tourism, airlines, restaurants, hotels, telecom service centers, retail, etc. Most of the sectors in different countries were partially or completely closed because of the rapid transmission of the virus, while the service sector was the most affected. The service sector faced complete closure because of 
direct human contact and the rules of social distancing [7], especially tourism, health, media and entertainment, and transport industries [8]. In these sectors, employees are at more risk of contracting coronavirus because they have to interact with customers directly and come in direct or indirect contact with many customers, or they must manage items used or touched by the consumers [9]. Along with this fear of the virus, employees of different sectors faced various issues related to reduced salary or job loss. Many people lost their job because businesses are shut down or there were fewer sales. The impact of COVID19 is detrimental for people, businesses, and the economy as well [10]. Subsequently, this pandemic has caused severe stress among employees and has directly affected their attitude, behavior, and performance at the workplace.

The work functioning has changed drastically, and COVID-19 has forced people to deal with this change in the work environment. In a study conducted by Li et al. [2], it was reported that to foster employee and organizational relationships and to reduce uncertainties during organizational change, transparent internal communication can play a vital role. Many studies have been conducted involving different sectors in various countries to understand the impact of COVID-19 on the operational working of businesses and organizations. For instance, the hospitality industry [11], tourism [12,13], restaurants [14], aviation industry [15], retail industry [16], etc. The pandemic not only affected the operations of the industries but also posed a negative impact on the work behaviors of the employees. Hence, researchers are keen to understand the impact of various factors on the organizational behavior of the employees. Several behavioral studies were conducted for a better understanding of employee behavior during COVID-19. These studies include factors like organizational leadership [17], employee stress [18], organizational citizenship behavior [1], job satisfaction [19], organizational commitment [20], and employee performance [21,22].

It was reported by different studies that employees' behaviors may change during pandemics. For example, several studies reported that impact of this pandemic resulted in reduced employee engagement because of remote jobs [23] and job insecurity [24]. However, one important influencer for employee engagement is perceived organizational support which refers to "an employee's perception that the organization values his or her work contributions and cares about the employee's well-being" [25] (p. 4), whereas it was found that the affective commitment of the employee may change positively towards the organization if the organization is facing a crisis during an external event, like wars or pandemics, in the country where it is operating [20]. This change may be a result of the emotional attachment of the employee to the organization [26]. On the other hand, the importance of organizational support for its employees increases during the pandemics, and it can affect their different behavioral outcomes like job anxiety [27], emotional exhaustion [28], employees work engagement [29], and organizational citizenship behavior [30]. Therefore, studying employee's behaviors during the pandemic is important to understand the role of organizational support.

According to Guadagno [31], foreign employees and employees with an immigration background are certainly more vulnerable and affected by the impacts of the COVID19 pandemic because of various reasons, such as their working and living conditions, linguistic diversity, inadequate health services, limited network or local knowledge, etc. In the opinion of Rudolph et al. [32], studying the impact of the COVID-19 pandemic on the organizational behavior of foreign or migrant workers is one of the most significant topics for future studies because these employees are more likely to perceive inequalities and are more vulnerable to the health and economic effects of the pandemic within the host country. Therefore, the current study is conducted to understand the organizational behavior of foreign employees working in the service sector in Hungary by examining the impact of perceived organizational support on the organizational citizenship behavior of the employees, with the mediating effect of affective commitment and employee engagement during the COVID-19 pandemic. 
According to Baksa et al. [33], foreign employees with full-time work contracts correspond to nearly 14 percent of the total employees working in the Hungarian service sector in 2020 with a slight decrease compared to previous years due to the current pandemic and the limitation of traffic. Moreover, many foreign students are employed in part-time work in different service sectors of Hungarian companies, and the total number of students enrolled in Hungarian universities is over 33,000 [34,35]. The Hungarian service sector is achieving $65.7 \%$ of the total GDP of Hungary [33], whereas private service companies are the most developed in Hungary and make up a high percentage of the entire service sector in Hungary [36]. Hence, it is crucial to understand the organizational behavior of foreign employees working in the service sector in Hungary during the COVID-19 pandemic.

The main aim of this study is to examine the impact of perceived organizational support (POS) on organizational citizenship behavior (OCB) of the foreign employees working in the service sector in Hungary because it is crucial to examine the behavior of the employees towards their organization during the COVID-19 pandemic. The study is conducted to provide a comprehensive framework to investigate the relationship between variables related to organizational behavior of the employees, such as POS, employee engagement, affective commitment, and OCB. To achieve this purpose, a quantitative approach was applied, and a structured questionnaire was used to collect the data. The questionnaire was sent to the employees by using an online form because it is the most convenient way to gather the data at the time of pandemic. The target population for this study is foreign employees working as a full-time and part-time employee in different companies of the service sector in Hungary. To analyze the relationship between abovementioned variables, structural equation modeling (SEM) was used. The advantage of using SEM is that it can help in identifying the influence and weight of several variables on one variable. It also helps in analyzing the moderating and mediating effects of the variables. This method provides clear and better understanding for the readers to assess the relationship between the studied variables.

This study will try to answer the following questions: What is the influence of perceived organizational support (POS) on organizational citizenship behavior (OCB) of the foreign employees during the COVID-19 pandemic in Hungary? What is the role of employees' engagement and affective commitment in strengthening the relationship between POS and OCB among foreign employees working in Hungary? Is there any direct impact of employee engagement and affective commitment on OCB of these employees during the COVID-19 pandemic? The current research will provide novel results for the researchers and managers for a better understanding of employee behavior in this context. The lack of literature on the current topic in the context of the COVID-19 pandemic has created a need for this study to identify the influence of these constructs on OCB of the employees. The research was conducted by incorporating variables like POS, employee engagement, and affective commitment, and it provided evidence of their influence on OCB during COVID-19. To the best of the authors' knowledge, none of the studies has been conducted during the COVID-19 pandemic which examined the impact of POS on OCB on foreign employees working in the service sector in Hungary. Therefore, this study attempted to fill the research gap by analyzing the impact of POS on OCB, and by examining the potential role of employee engagement and affective commitment in mediating this relationship of POS and OCB among the foreign employees who are considered the most vulnerable to the COVID-19 pandemic.

This study will first present the review of previous literature and distinguish the present study from previous studies conducted during and before the COVID-19 pandemic. Then, the sample collection, sampling method, applied materials and methods will be clarified. Next, the study will define the analysis to test the reliability and validity of the collected data. After that, model fit was tested by using confirmatory factor analysis and structural equation modeling (SEM) was applied to test and explain the proposed hypotheses. In the next section, results are presented and thoroughly discussed by presenting related or contrary evidence from previous studies. In the last section, implications, 
recommendations, conclusions, and limitations along with future research directions are provided.

\section{Literature Review}

\subsection{Perceived Organizational Support}

Eisenberger et al. [25] defined perceived organizational support (POS) as "the extent to which it is perceived by employees that organizations value their contributions and care about the well-being of employees" (p. 3). Eisenberger et al. [37] stated that when employees realized that they are supported and valued by their organization, they work more efficiently for the value and success of the organization. According to Jain and Sinha [38], POS signifies the efforts, social affection needs, loyalty, and commitment of an individual identified by the organization. Rhoades and Eisenberger [39] contemplated POS as the contribution of an organization to gain mutual benefits with employees because the employees act better in paying back the positive effects of the organization. Le and Lei [40] argued that POS indicates the best efforts of employees to act according to the goals of the organization and perform personal duties as a positive response which derives from their acceptance of being valued and care of their well-being, also by having considerable support of the organization.

\subsection{Affective Commitment}

Meyer and Allen [41] stated that organizational commitment is a behavior that combines a person's identity with the organization so that the organizational and individual goals become consistent. In previous literature, it was proven that employees who possess less commitment towards their organization tend to make more mistakes at the job, experience more stress, have more family-related conflicts, and become more absent on the work in comparison to the employees having strong organizational commitment [42]. Many studies underlined that organizational commitment comprises three components that are continuance commitment, normative commitment, and affective commitment [43,44]. According to Ko et al. [44], affective commitment is the desire to stay employed in the organization that derives from recognition, emotional attachment, and participation with the organization. Compared with normative and continuance commitment, affective commitment is related to positive organizational results like job performance, $\mathrm{OCB}$, and employee engagement [45-47].

\subsection{Employees Engagement}

Employees' engagement is defined as "a positive, fulfilling, work-related state of mind that is characterized by vigor, dedication, and absorption" [48] (p. 74). This definition indicated that there are three elements of employees' engagement: vigor (physical element), absorption (cognitive element), and dedication (emotional element). When mental resilience and immense energy are felt by the employees when they work, this is characterized as vigor. On the other hand, dedication involves inspiration, challenge, pride, significance, involvement, and enthusiasm at work. Lastly, absorption occurs when employees are immensely engaged in the work and possess a high concentration level as time changes rapidly and they feel it hard to disengage themselves from work [48]. Different antecedents of employees' engagement in previous literature are specified, and some of these antecedents are diversity management practices [49,50], green HRM [51], organizational justice [52-54], organizational commitment [55], leadership [56] conflict management [57] perceived organizational personal support [53,58-60]. Employee engagement is crucial for the growth and development of an organization because a high level of engagement leads to improved productivity. At the time of distress (e.g., COVID-19 pandemic), employee engagement is more important for organizational processes, and organizations should emphasize on employee engagement during pandemic [61]. 


\subsection{Organizational Citizenship Behavior}

Organizational citizenship behavior (OCB) is defined as an individual's chosen behavior which is not related to the formal reward system of an organization; rather, it increases the organizational effectiveness [62]. OCB as a construct was coined by Organ, who regarded it as a clearer interpretation of 'performance' in the arguments related to performance caused by satisfaction [63]. It is also referred to as the set of discretionary workplace behaviors which goes beyond one's fundamental job requirements and behaviors that go beyond the call of job responsibility [64]. According to Bienstock et al. [65], the major interest of OCB was to identify the responsibilities or behaviors of an employee who is sometimes inadequately measured or overlooked in the traditional measurements of the job performance of the employee, but who, on the other hand, enhances organizational effectiveness or functionality. In the last two decades, the exploration of reliable predictors of OCB has increased, and researchers attempt to find several factors that can predict OCB such as job satisfaction $[66,67]$, leadership style characteristics $[68,69]$, organizational commitment [60,70-72], perceived organizational support [45,66], and employees' engagement [73]. This study will further analyze the influence of a few of these predictors during the pandemic and will attempt to make a better understanding of the mediating impact of employee engagement and affective commitment between POS and OCB.

\subsection{POS and Employees Engagement}

In the boundaries of social exchange theory (SET), employee engagement seems to mediate the standards of the mutual benefits by assuring the loyalty of an individual for the sustenance and support of an organization. In the previous literature, it is indicated that positive effects and contributions are displayed by the employees when they feel an attachment between their organization and themselves [74]. On the basis of SET, the employees with high POS tend to become more involved with their work and organization to help in achieving organizational goals as part of SET's reciprocity norm [75]. In the context of organizational support theory, when it is perceived by the employees that management value their contribution and their well-being, then as a result they tend to use dedication, vigor, and absorption by using social exchange perspective in fulfilling their responsibilities at work [53,55]. For employee engagement, this view is widely accepted that it is a significant behavioral outcome of POS. It is accepted by previous studies that there will be a reinforcement of employee's emotional and cognitive appraisal at work and in their organization when employees have POS [75]. In service sector, several studies investigated the impact of POS on employees' engagement, for example, Imran et al. [60] in their study on employees from banking sector in Pakistan found that POS significantly and positively influence employees' work engagement. The same results were found in the study of Yang et al. [76], who conducted their study on the Chinese doctors working in health sector in China, and also in the study conducted by Rahman et al. [77] on employees of healthcare sector in Bangladesh. In other studies, this effect was found to be indirect and was associated with self-efficiency of the employees of education sector [29] and financial service sector [78]. Based on what was proposed above, the researchers could form a hypothesis:

Hypothesis 1 (H1). There is a positive significant effect of perceived organizational support on employee engagement.

\subsection{POS and Affective Commitment}

Affective commitment is mainly explained based on social exchange theory (SET) [79]. Furthermore, SET has been widely used to explain not only the relationship between POS and affective commitment but also the antecedents of organizational commitment in general [80]. Social exchange theory demonstrates that relationships evolve with time into loyalty, trust, and mutual commitments [81]. This means that high-quality relationships of social exchange are facilitated by successful reciprocal exchanges because individuals are 
encouraged to pay back the desired treatment they have received [82]. In this context, when employees perceive support from their organization, this support will prompt them to strengthen their contribution to their work. Furthermore, it boosts the expectation that their risen contributions will be noticed and then rewarded as well; as a result, it will motivate individuals to dedicate more efforts and time in their job [39]. This increased dedication can be displayed by voluntarily extending an individual's work role to incorporate such activities that were not present in the formal work description [83].

Studies on affective commitment based on social exchange theory have found that one important influencer of affective commitment is POS, and this effect can be direct $[60,84]$ in both banking and trade sectors, or indirect $[80,85]$ in banking and education sectors. Based on what has proposed above, the researchers hypothesized the following:

Hypothesis 2 (H2). There is a positive significant effect of perceived organizational support on affective commitment.

\subsection{POS and $O C B$}

It is postulated by social exchange theory (SET) that employees who believe that their contribution is valued by their organization-either by involving them in the leading workforce or in any other way-will then return the favor to the organization as a duty by their positive behavior which includes organizational citizenship behavior and job performance $[79,86]$. The factors that lead to OCB are described by using this theory, e.g., [87,88] as an employee is obligated to give back with their positive behavior when these employees are supported by their organizations $[89,90]$. This theory suggested that if employees perceive higher value, care, and support from their organization (like POS), then they return more by displaying positive behavior, for instance, psychological capital, and therefore develop a higher level of OCB. A study conducted by Settoon et al. [91] involving hospital workers found that POS does not support positive influence on OCB; rather, it depicts interpersonal helping more than citizenship behavior. In recent years, the same results were found in other studies [60,92]. Contrary to this, Wayne et al. [93] in their study found that POS had a strong positive relationship with citizenship behavior on both individual and organizational levels. Similarly, different researchers supported a strong positive relationship between POS and OCB $[45,94,95]$. In a recent study that focused on +65 employees in Poland, [96] explained that when employees perceive positive attitudes and support from their human resource management (HRM) and organizations, they tend to have higher OCB, well-being, and job security. Furthermore, the perception of employees towards the involvement and perceived support from their HRM enhance their organizational engagement and $\mathrm{OCB}$, and this relationship might be affected indirectly by the employees' commitment to change [30].

Therefore, the following hypothesis was formulated:

Hypothesis 3 (H3). There is a positive significant effect of perceived organizational support on $O C B$.

\subsection{Employee Engagement and $O C B$}

The social exchange perspective and organizational support rationalize that engaged employees probably exhibit good attitudes and trust in their organization and management [94]. Thakre and Mathew [97], in their study on employees of the service sector in India, stated that employee engagement is considered a predictor of constructive results in an organization like job expectations and OCB. The COVID-19 pandemic has created a need for more employee engagement and support for survival and better growth of an organization [5]. Engaged employees are more likely to display OCB because they feel that they can accept additional responsibilities by accomplishing their tasks efficiently [98]. Several studies in the past have supported the positive association between employees' engagement and OCB in different service sectors like the health sector [94], banking sec- 
tor [95], public sector [99], and the trade services sector [100]. However, in the current scenario of the pandemic, this association necessitates investigation. Hence, the following hypothesis is suggested:

Hypothesis 4 (H4). Employee engagement positively influences OCB.

\subsection{Affective Commitment and $O C B$}

Affective commitment often precedes positive organizational outcomes, for instance, better performance, increased efficiency, reduced absenteeism [101]. It is also regarded as a psychological contract that corresponds to long-term loyalty promise from employees if their organization ensures promotion opportunities, job security, and self-development [102]. Additionally, Wang et al. [103] asserted that if employees receive employer's support mainly at the time of distress, then they are more likely to show positive behavior and commitment at the workplace, and it reciprocates into increased OCB. This is true during the distress caused by the COVID-19 pandemic, which indicates that during the challenging scenario, if the employees are satisfied with their work-life, then they exhibit a low level of intentions to leave the organization or high level of OCB [104]. Similarly, previous literature has proven a positive relationship between affective commitment and OCB in banking and financial sectors $[67,69]$. Therefore, we proposed the following hypothesis:

Hypothesis 5 (H5). Affective commitment positively influence OCB.

\subsection{Employee Engagement as a Mediator between POS and OCB}

In literature, many studies have confirmed the significant positive relationship between POS and OCB $[66,93,105]$. However, researchers also aimed to understand the mediating effect of these factors between POS and OCB $[45,95]$. Hence, this study incorporated the role of employee engagement as a mediator between POS and OCB. Sulea et al. [98] suggested that different job characteristics like POS and conscientiousness are positively associated with employee citizenship behavior through employee work engagement. Other studies also supported the mediation effect of employee engagement in this context [106,107], but it is crucial to understand its influence during the COVID-19 pandemic. Therefore, the following hypothesis is suggested:

Hypothesis 6 (H6). Employee engagement mediates the relationship between POS and OCB.

\subsection{Affective Commitment as a Mediator between POS and OCB}

According to the theoretical framework suggested by Piercy et al. [108], it was asserted that commitment can serve as a mediator in the relationship between POS and OCB. It gives the supporting logic for an association of commitment and POS [84], and commitment and OCB $[60,70,72]$. In a study conducted on the professional employees in the health care sector in Canada, the organizational commitment was found to mediate the relationship between POS with both OCB and employees' satisfaction of these employees; moreover, the study found that the perceptions of these employees toward HRM practices were more effective in enhancing OCB when it was associated with a positive POS to organizational commitment pathway [109]. Two other studies that were applied on the expatriates working in different sectors in China [110] and Kuwait [45] have supported the mediating influence of commitment between POS and OCB. Based on previous findings and support for the POS, affective commitment, and OCB relationship, it is suggested to integrate affective commitment as a mediating variable in this study. Hence, this hypothesis is suggested:

Hypothesis 7 (H7). Affective commitment mediates the relationship between POS and OCB.

The conceptual framework and the hypotheses are presented in Figure 1. 


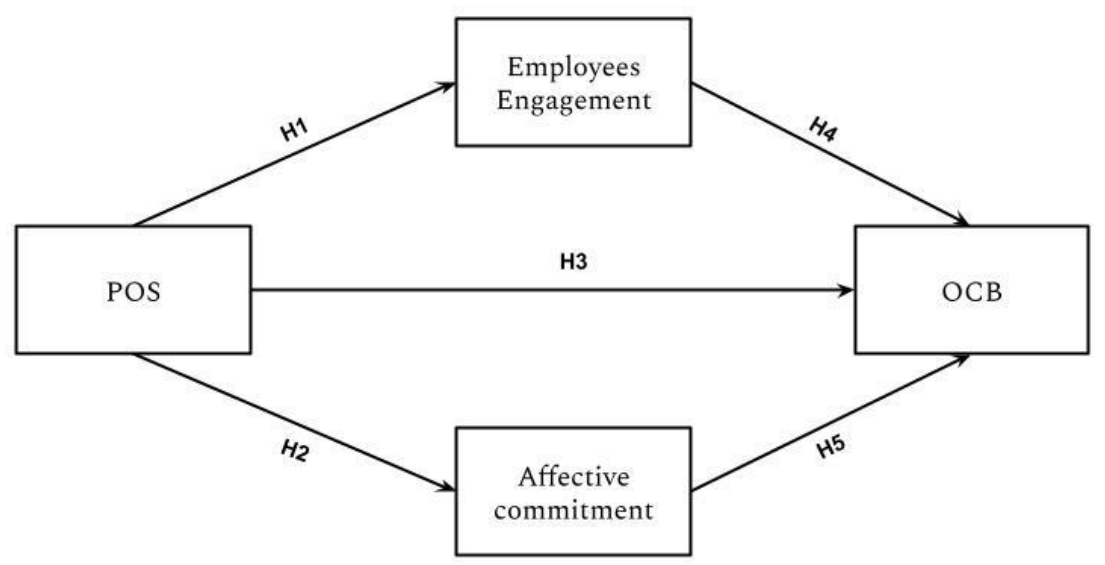

H6: POS $\rightarrow$ employees engagement $\rightarrow$ OCB

H7: POS $\rightarrow$ Affective commitment $\rightarrow$ OCB

Figure 1. Conceptual framework of the study.

\section{Methods}

\subsection{Sample and Procedures}

The current study aims to investigate the impact of POS on OCB, and how employee engagement and affective commitment can mediate this relationship-moreover, to find out which mediator plays a more significant role in this relationship, and to figure out what effects of POS are posed on employees' engagement and affective commitment. Finally, to determine whether employees' engagement or affective commitment can affect more OCB among the foreign employees in the Hungarian private service sector. The target population of this research is foreign employees working in different private companies in the service sector located in Hungary. A structured questionnaire with an introduction message that explains the aim of the study was used to gather the data. The linear snowball sampling method was used, and an electronic questionnaire using online channels was distributed to employees, working in full time or part time jobs. Around 600 requests were sent to the employees to participate in the survey, and out of these, 380 responses were valid with no missing values and used for analysis, with a rate of answer (about 63.33\%) which is considered a reasonable response rate [111]. Table 1 shows the personal traits of the sample.

As it could be noticed from the table above, females had a higher count $(\mathrm{N}=191)$. The highest percentage of $48.1 \%$ was for employees with more than a year and less than five years of work tenure. Besides, it could be noticed that the highest percentage $(68.9 \%)$ of employees belongs to the age group of 25-34 years. Finally, the majority of the employees $(\mathrm{N}=142)$ were working in financial and trade companies that provide professional financial services.

\subsection{Measures}

Employees reported their levels of POS, employee engagement, affective commitment, and OCB through a standard online questionnaire comprising four sections:

Perceived organizational support: an 8-item scale was used in the study adapted from [37] which originally has 17 items; however, the recommendation of the 8 -item scale was followed which is given by Rhodes and Eisenberger [39] (p. 699) who mention that, "because the original scale is unidimensional and has high internal reliability, the use of shorter versions does not appear problematic." Therefore, the researchers decided to use the shorter version. It is based on a 5 point Likert scale in which 1 signifies "totally disagree" to 5 signifies "totally agree". The unidimensionality, predictive validity, and reliability of the scale have been reported from extensive evidence [39]. The sample items include, "The organization cares about my general satisfaction at work." 
Affective commitment: items for this construct were taken from the study of [112] in which the six-item scale of affective commitment was used. Meta-analytic evidence for the predictive validity and high reliability of the scale has been found [42]. This scale used a 5 point Likert scale ( 1 totally disagree to 5 totally agree). The sample items include, "Right now, staying with my organization is a matter of necessity as much as desire."

Employee engagement: this construct was taken from the short version of the Utrecht Work engagement scale (nine items), which uses a seven point scale (where 0 is never, and 6 is always) [48]. The scale is widely used, and its high reliability and validity have been verified in different studies. One sample of the items is, "When I get up in the morning, I feel like going to work".

Organizational citizenship behavior: this part was adopted from [113], and a ten-item scale was used where ( 1 is never, 5 is always). The evidence of the scale's high reliability and validity was tested and proved by Becker and Randall [114]. One sample of the items is, "Volunteered for things that were not required".

Table 2 indicates the descriptive statistics of the variables under study and the correlation among them.

Table 1. Respondents' personal characteristics $(\mathrm{N}=380)$.

\begin{tabular}{|c|c|c|c|}
\hline Traits & Item & Count & $\%$ \\
\hline \multirow{3}{*}{ Gender } & Male & 182 & 47.9 \\
\hline & Female & 191 & 50.3 \\
\hline & Prefer not to say & 7 & 1.8 \\
\hline \multirow{4}{*}{ Work tenure } & less than one year & 118 & 31.1 \\
\hline & $\begin{array}{c}\text { More than one year to } \\
\text { five years }\end{array}$ & 183 & 48.1 \\
\hline & $\begin{array}{l}\text { More than five years } \\
\text { to ten years }\end{array}$ & 65 & 17.1 \\
\hline & Above ten years & 14 & 3.7 \\
\hline \multirow{5}{*}{ Age } & $18-24$ & 61 & 16.1 \\
\hline & $25-34$ & 262 & 68.9 \\
\hline & $35-44$ & 42 & 11.1 \\
\hline & $45-54$ & 15 & 3.9 \\
\hline & Above 55 & 0 & 0 \\
\hline \multirow{7}{*}{ Company's sector } & Hospitality & 25 & 6.6 \\
\hline & Tourism & 68 & 17.9 \\
\hline & Financial and trade & 142 & 37.5 \\
\hline & Health care & 10 & 2.5 \\
\hline & Entertainment & 8 & 2.1 \\
\hline & Transportation & 15 & 3.9 \\
\hline & Other & 112 & 29.5 \\
\hline
\end{tabular}

Table 2. Correlations and descriptive analysis.

\begin{tabular}{lcccccc}
\hline \multicolumn{1}{c}{ Variables } & Mean & SD & $\mathbf{1}$ & $\mathbf{2}$ & $\mathbf{3}$ & $\mathbf{4}$ \\
\hline 1. Employees Engagement & 3.775 & 0.973 & - & & & \\
2. Affective commitment & 3.301 & 0.685 & $0.258^{* *}$ & - & & \\
3. POS & 3.258 & 0.627 & $0.502^{* *}$ & $0.351^{* *}$ & - & \\
4. OCB & 3.242 & 0.560 & $0.671^{* *}$ & $0.263^{* *}$ & $0.342^{* *}$ & - \\
\hline
\end{tabular}

${ }^{* *} p<0.01$. Note: POS: Perceived organizational support, OCB: Organizational citizenship behavior.

\subsection{Common Method Bias}

In common method bias, the variance is "attributable to the method of measurement instead of the measures that represent the constructs" [115] (p. 879). The validity of the results of the study threatens by having this bias [116]. Hence, the study applied Herman's one-factor test to examine the occurrence of common method bias. To fulfill the criteria, all 
studied variables were loaded into an explanatory factor analysis (EFA) with no rotated factor solution and by restricting extracted factor number to one. The results of the Herman test revealed that one-factor solutions described only $17.56 \%$ of explained variance, which is far less than the accepted maximum variance of $50 \%$ of the common method variance in Herman's one-factor test [117]. This implies that the potential threat for the common method variance of the study remains limited so further analysis can be performed.

\subsection{Reliability Test}

To test the reliability of the dataset before analyzing the results, a reliability test has been conducted. The results suggest the value of Cronbach's alpha for each construct is above 0.7 , which indicates that the reliability of the factors is very high. The acceptable values for reliability level are above 0.6 for all constructs to be considered as satisfactorily reliable [118]. Table 3 presents the reliability test results.

Table 3. ICR and Convergent Validity.

\begin{tabular}{|c|c|c|c|c|c|}
\hline Variables & Items & Items Loadings & CR & AVE & Alphas Cronbach \\
\hline \multirow{9}{*}{$\begin{array}{l}\text { Employee's } \\
\text { engagement }\end{array}$} & Eng1 & 0.610 & \multirow{9}{*}{0.90} & \multirow{9}{*}{0.51} & \multirow{9}{*}{0.876} \\
\hline & Eng2 & 0.780 & & & \\
\hline & Eng3 & 0.761 & & & \\
\hline & Eng4 & 0.803 & & & \\
\hline & Eng5 & 0.699 & & & \\
\hline & Eng6 & 0.664 & & & \\
\hline & Eng7 & 0.695 & & & \\
\hline & Eng8 & 0.744 & & & \\
\hline & Eng9 & 0.662 & & & \\
\hline \multirow{10}{*}{ OCB } & OCBs1 & 0.763 & \multirow{10}{*}{0.92} & \multirow{10}{*}{0.55} & \multirow{10}{*}{0.819} \\
\hline & OCBs2 & 0.785 & & & \\
\hline & OCBs3 & 0.766 & & & \\
\hline & OCBs4 & 0.735 & & & \\
\hline & OCBs5 & 0.694 & & & \\
\hline & OCBs6 & 0.666 & & & \\
\hline & OCBs7 & 0.799 & & & \\
\hline & OCBs8 & 0.770 & & & \\
\hline & OCBs9 & 0.699 & & & \\
\hline & OCBs10 & 0.689 & & & \\
\hline \multirow{8}{*}{ POS } & POSs1 & 0.786 & \multirow{8}{*}{0.83} & \multirow{8}{*}{0.608} & \multirow{8}{*}{0.734} \\
\hline & POSs2 & 0.811 & & & \\
\hline & POSs3 & 0.776 & & & \\
\hline & POSs4 & 0.681 & & & \\
\hline & POSs5 & 0.856 & & & \\
\hline & POSs6 & Item deleted. ${ }^{\mathrm{a}}$ & & & \\
\hline & POSs7 & Item deleted. ${ }^{\mathrm{b}}$ & & & \\
\hline & POSs8 & 0.710 & & & \\
\hline \multirow{6}{*}{$\begin{array}{c}\text { Affective } \\
\text { commitment }\end{array}$} & $\mathrm{AC} 1$ & 0.754 & \multirow{6}{*}{0.88} & \multirow{6}{*}{0.60} & \multirow{6}{*}{0.743} \\
\hline & AC2 & 0.763 & & & \\
\hline & AC3 & 0.674 & & & \\
\hline & $\mathrm{AC} 4$ & 0.798 & & & \\
\hline & AC5 & 0.790 & & & \\
\hline & AC6 & 0.833 & & & \\
\hline
\end{tabular}

Notes: AVE, Average variance extracted, CR, composite reliability, $\mathrm{POS6}^{\mathrm{a}}{ }^{\text {, }} \mathrm{POS}^{\mathrm{b}}$ deleted due to low factor loadings.

\subsection{Validity Test}

After conducting a reliability test, the validity test is necessary to examine the validity of the data.

To assess the validity of the constructs, the researchers used the EFA test by using the principal component analysis with varimax rotation and eigenvalue greater than 
one. The KMO (Kaiser Myer Olkin) test and Bartlett's test were used to recognize the factor analysis suitability. The value of $\mathrm{KMO}$ test was $72.5 \%$, which is higher than the threshold of $60 \%$, indicating a good sampling adequacy [119] with a significance level of $p<0.001$. This indicates that the data was suitable for conducting factor analysis. The factors were explaining a total variance of $71.6 \%$, which was higher than the value $50 \%$ as was recommended by [120]. The items loading values are shown in Table 3.

Then a confirmatory factor analysis (CFM) was applied to test and check the variables, and a convergent validity $(\mathrm{CV})$ test was used for this purpose. CV measures "the extent to which a measure correlates positively with alternative measures of the same constructs" [121] (p. 112). It is required to check the average variance extracted (AVE) and outer loading values of the items for assessing the CV of the variables. The items with low outer loadings can be retained if other items with higher loadings explain around 50 percent $(\mathrm{AVE}=0.50)$ of the variance Hair et al. [121]. Therefore, two items (POS_6, POS_7) were removed because of weak outer loadings. Then, AVE was obtained after removing these items, and it was found to be adequate for all the constructs.

Composite reliability (CR) is the second validity measurement test. According to Hair et al. [121], the measure of internal consistency was assessed by CR. The threshold value of CR above 0.7 for each construct is satisfactorily acceptable [122,123]. Table 3 shows the internal consistency reliability (ICR) and convergent validity.

\subsection{Model Fit}

According to Hair et al. [124], before making the conclusions, diagnosing the model's goodness of fit indices is essential. Some of the common indices used for this purpose are the degree of freedom of the model (df), comparative fit index (CFI), the model's chi-square $(\mathrm{X} 2)$, standardized root mean residual (SRMR), the Tucker-Lewis index (TLI), and the root mean square error of approximation (RMSEA). It is required for the good model fit measure to meet the accepted limits of these indices. The suggested limits or threshold values are RMSEA $\leq 0.09, \mathrm{X} 2 / \mathrm{df}<5, \mathrm{SRMR}<0.06$, TLI closes to 1 , and CFI $>0.9[125,126]$. Hence, before conducting the final analysis, it is important to evaluate the model's goodness of fit. The results in Table 4 indicate a good fit for each construct. In this study, the model fit will provide a basis to test the hypotheses.

Table 4. Goodness of fit statistics.

\begin{tabular}{cccccccc}
\hline Fit Index & $\chi^{2}$ & df & $\chi^{2} / \mathbf{d f}$ & TLI & CFI & RMSEA & SRMR \\
\hline Value & 3.869 & 1 & $3.869 *$ & 0.96 & 0.99 & 0.08 & 0.03 \\
\hline${ }^{*} p<0.05$. & & & & & & &
\end{tabular}

\section{Results}

\subsection{Data Analysis}

To assess the hypothesis, the researchers used structural equation modeling (SEM) by using AMOS 22 package. The relationship between independent and dependent variables was determined, and for this, SEM is applied by using a covariance matrix. Likewise, SEM is used to examine the weight and influence of the independent variables over dependent variables. The ability to simultaneously conduct confirmatory factor analysis (CFA) and regression analysis is the main advantage of SEM, which also helps in examining moderation or mediating effects $[127,128]$.

The two-step mediation process which is suggested by Hair et al. [129] was used to test the hypothesized mediating relationship by using SEM. To test the significance of both direct effects among $X$ and other two variables is the first step in this two-step mediation analysis, along with mediated or indirect effect $(\mathrm{X} \rightarrow \mathrm{M} 1 \rightarrow \mathrm{Y})$ and $(\mathrm{X} \rightarrow \mathrm{M} 2 \rightarrow \mathrm{Y})$ as advised by Hair et al. [128]. For this, SEM's path analysis techniques were used. It is used to assess whether there exists mediation or no effect, and to examine the type of mediation i.e., full or partial mediation. The method of Sobel-based mediation test for variables was 
employed in this research as assessment which is following [124] (p. 89) criteria: who described these steps as follows (see Figure 2):

1. If $a, b$ and $c$ are significant but the direct coefficient value is $c<b$, then it is partial mediation.

2. If $\mathrm{a}$ and $\mathrm{b}$ are significant, but $\mathrm{c}$ is not significant, then it is full mediation.

3. If $\mathrm{a}$ is significant, $\mathrm{b}$ is significant and $\mathrm{c}$ is also significant, but the coefficient value is $c=b$, it is not mediation.

4. If $\mathrm{a}$ or $\mathrm{b}$ or both are insignificant, it is not mediation.

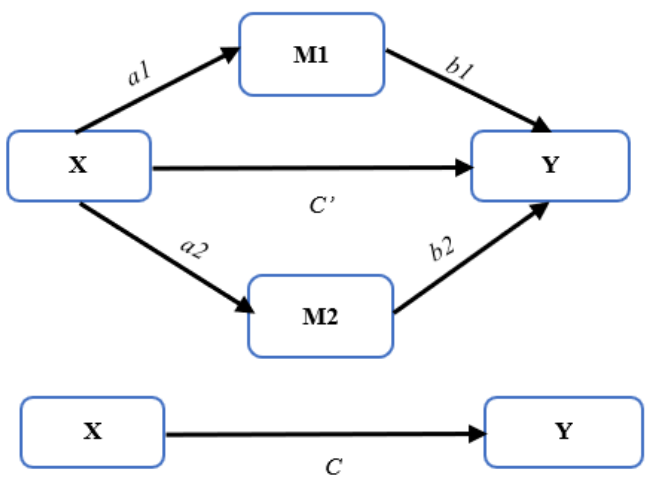

Figure 2. Theoretical role of mediation.

The data first entered on SPSS V25 package, prepared and coded as it was mentioned in the measures, then the reliability and validity tests were done, and the mean score of the answers of each variable was calculated. After that the data was imported into AMOS v22, and the SEM was run.

\subsection{Hypotheses Test}

The results of SEM analysis are presented in Table 5, which shows that POS is associated directly with organizational citizenship behaviors $(\beta=0.342, p<0.001)$, indicating that the more organizational support is perceived by the employees the higher organizational citizenship they will have. In addition, the path analysis revealed that POS is positively associated with employee engagement $(\beta=0.502, p<0.001)$ and affective commitment $(\beta=0.384, p<0.001)$. These results have proved hypotheses $(\mathrm{H} 1, \mathrm{H} 2, \mathrm{H} 3)$, which indicates that there is a direct effect of POS on both employee engagement and affective commitment.

Furthermore, both employees' engagement and affective commitment are positively associated with OCB (EE $\rightarrow$ OCB: $\beta=0.660, p<0.01$ ); (AC $\rightarrow$ OCB: $\beta=0.103, p<0.001$ ). Hence, the results confirmed hypotheses (H4, H5), which implies that employee engagement and affective commitment are significantly and positively associated with OCB.

Following the method of Hair et al. [124], which asserts that "full median exists if (a) and (b) direct effects are significant but (c) is not significant", it is evident from the results (Table 5) that employee engagement positively and significantly mediates the effect of POS on $\mathrm{OCB}$, and this mediation is considered a full mediation. Similarly, affective commitment significantly and positively mediates the relationship between POS and OCB, and this mediation is full mediation as well because the direct effect (path $\mathrm{c}^{\prime}$ ) became insignificant and decreases pointedly $(\beta=-0.024, p=0.600)$ in the existence of employee's engagement and affective commitment.

As it could be noticed, employee engagement acts as a strong mediator compared to affective commitment. This means that the influence of perceived organizational support of the employees on their organizational citizenship behavior can be explained by the presence of employee engagement and affective commitment together. If employees are getting more committed or engaged at work, then it is more likely that their perceived organizational support will be reflected positively on their organizational citizenship behavior. These results support hypotheses $\mathrm{H} 6$ and H7, which assert that employee's engagement and 
affective commitment mediates the relationship between POS and OCB positively. The hypothesis test results in this research with SEM standardized estimates are presented in Figure 3. The results indicated that all proposed hypotheses of this study were supported.

Table 5. Results of SEM path coefficients.

\begin{tabular}{|c|c|c|c|c|c|c|c|}
\hline Path Code & Structural Paths & Estimate & $\beta$ & SE & CR & Sig & Information \\
\hline Path a1 & $\begin{array}{c}\text { POS } \rightarrow \text { Employee } \\
\text { engagement }\end{array}$ & 0.779 & 0.502 & 0.069 & 11.301 & $* * *$ & \multirow{3}{*}{$\begin{array}{c}\text { Paths a1, b1 are significant, while } \mathrm{c}^{\prime} \text { is } \\
\text { not significant: (full mediation), (H1, } \\
\text { H4, H6) supported }\end{array}$} \\
\hline Path b1 & $\begin{array}{c}\text { Employee engagement } \\
\rightarrow \text { OCB }\end{array}$ & 0.378 & 0.660 & 0.033 & 2.512 & 0.012 & \\
\hline Path $c^{\prime}$ & $\mathrm{POS} \rightarrow \mathrm{OCB}$ & -0.021 & -0.024 & 0.040 & -0.524 & 0.600 & \\
\hline Path a2 & $\begin{array}{c}\text { POS } \rightarrow \text { Affective } \\
\text { commitment }\end{array}$ & 0.384 & 0.351 & 0.053 & 7.308 & $* * *$ & \multirow{2}{*}{$\begin{array}{c}\text { Paths a2, b2 are significant, while } c^{\prime} \text { is } \\
\text { not significant: (full mediation) (H2, } \\
\text { H5, H7) supported) }\end{array}$} \\
\hline Path b2 & $\begin{array}{c}\text { Affective commitment } \\
\rightarrow \text { OCB }\end{array}$ & 0.083 & 0.103 & 0.025 & 14.964 & $* * *$ & \\
\hline Path c & $\mathrm{POS} \rightarrow \mathrm{OCB}$ & 0.311 & 0.342 & 0.043 & 7.080 & $* * *$ & H3 supported \\
\hline \multicolumn{7}{|c|}{ Indirect effects } & \\
\hline \multicolumn{3}{|c|}{ POS $\rightarrow$ Employee engagement $\rightarrow$ OCB } & \multicolumn{3}{|l|}{0.331} & \multicolumn{2}{|l|}{$* * *$} \\
\hline \multicolumn{3}{|c|}{ POS $\rightarrow$ Affective commitment $\rightarrow$ OCB } & 0.036 & & & \multicolumn{2}{|l|}{$* *$} \\
\hline \multirow{3}{*}{$\mathrm{R}^{2}$} & \multicolumn{4}{|c|}{ Affective commitment } & & \multicolumn{2}{|l|}{0.124} \\
\hline & \multicolumn{4}{|c|}{ Employee engagement } & & \multicolumn{2}{|l|}{0.252} \\
\hline & \multicolumn{4}{|c|}{ Organizational citizenship behavior } & & \multicolumn{2}{|l|}{0.453} \\
\hline
\end{tabular}

Note: POS: Perceived organizational support, OCB: organizational citizenship behavior, $\left.{ }^{* * *} p<0.001,{ }^{* *} p<0.05\right)$.

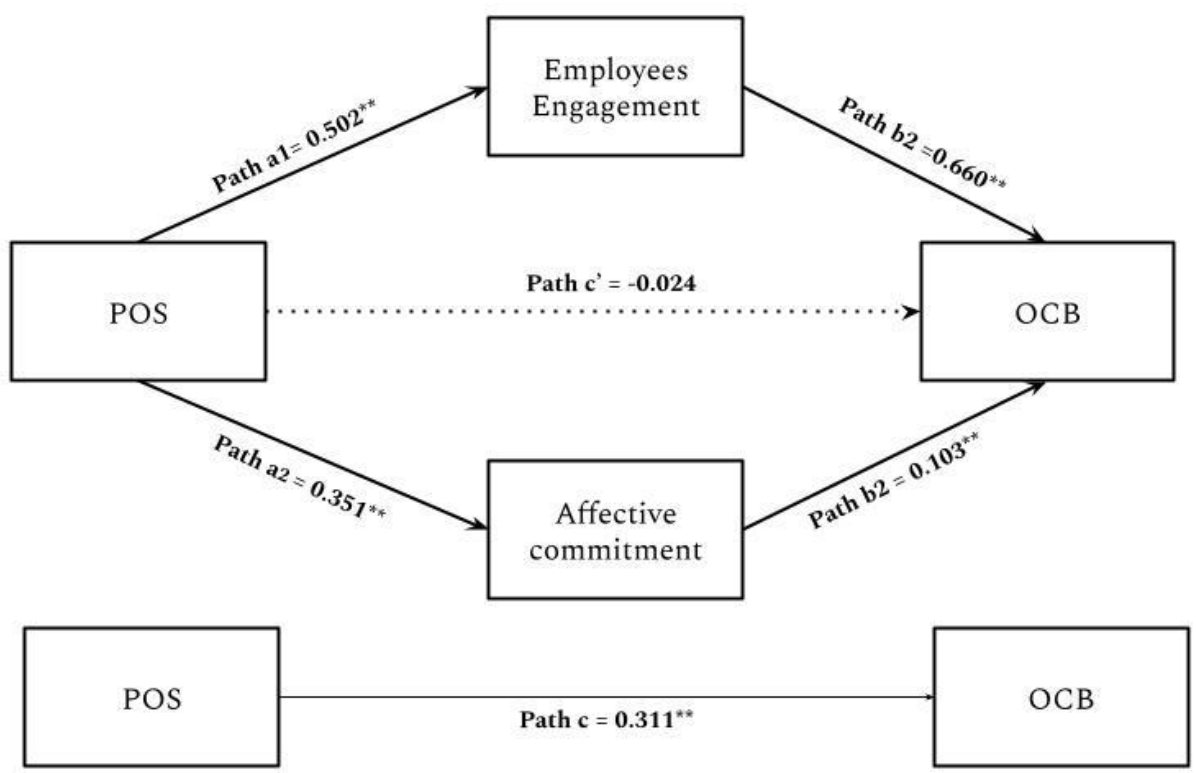

Figure 3. hypothesis results. ${ }^{* *} p<0.01$.

The study's model explained a reasonable proportion of variance in affective commitment $\left(R^{2}=12.4 \%\right)$, employees' engagement $\left(R^{2}=25.2 \%\right)$, and OCB $\left(R^{2}=45.3 \%\right)$.

\section{Discussion}

The study intended to find out how POS can enhance citizenship behaviors among foreign employees who work in the private service sector companies in Hungary. Furthermore, the study tried to find out the role of employees' engagement and affective commitment in this relationship. For achieving this study purpose, the researchers used a sample from the foreign employees employed in the private service sector in Hungary because of its importance in the country [33].

Consistent with social exchange theory (SET), perceived organizational support was positively associated with $\mathrm{OCB}$ (in the absence of the mediators). This result is in accordance 
with Muhammad [44], who found that POS is positively related to higher levels of OCB directed to the organization. On the other hand, this result is in disagreement with other studies that could not find any significant direct effect of POS on OCB [60,92].

The study results revealed that perceived organizational support is an important influencer of employee engagement. This implies that the more organizational support is perceived by the employees, the more likely they will be engaged at work, and it is clearly in accordance with social exchange theory which highlights a social contract between employees and organization. The employees who are showing increased engagement at their workplace during the COVID-19 pandemic acknowledged the social and economic benefits from their organization. Hence, the results suggest that more organizational support at the time of disruption will lead to more employee engagement at work. This result is in line with previous studies that support a direct positive relationship between POS and employee engagement $[99,129]$. On the other hand, the results indicated that perceived organizational support could positively affect affective commitment, indicating that the more organizational support is perceived by the employees, the more likely they will have positive feelings of commitments toward their organization. This result is supported by other studies as well $[60,130]$.

The findings also indicated that employee engagement could affect OCB positively in the time of COVID-19. This result agrees with previous studies which indicated the role of employee engagement at work in predicting OCB during the pandemic $[97,131,132]$. Furthermore, the findings of this study related to the impact of affective commitment on OCB agrees with the result of previous studies [60,70-72].

The results also revealed that employee engagement could be a strong mediator between POS and OCB, which implies that, if employees are more engaged at work, then it is more likely that the perceived organizational support will affect their organizational citizenship behavior $[92,106]$. Furthermore, an affective commitment was also found to mediate the effect of POS on OCB positively [45]. However, it could be noticed that employee engagement dominated the mediation effect more as compared to affective commitment. In flatter, the more employees will be engaged at work and emotionally attached to their organization, the more likely their perceived organizational support will influence their organizational citizenship behaviors; however, their engagement at work is more important in changing their OCB. According to Hu et al. [133], fear of the COVID-19 pandemic may affect the employees' engagement at work. In this regard, POS might control this change in employee engagement by recovering the decreased engagement at work which resulted from insecurity or fear of the pandemic [28]. Therefore, our results indirectly interfere with these results assuring the important role of POS in enhancing employee engagement at work, which in turn will enhance OCB during the COVID-19 pandemic [132].

\section{Theoretical and Practical Implications}

To date, there have been limited international studies that explore the direct or indirect relationship between POS and OCB despite growing interest in both constructs. Therefore, this study significantly contributes to the theory in the field of human resource management and organizational behavior. This study was conducted during the COVID19 pandemic which has affected the employees' behaviors and their way of perceiving organizational support, especially the employees' cognitive behaviors [134]. The change in work environment and business operations because of the COVID-19 pandemic has resulted in a change in employee behavior. Hence, it is crucial to identify the organizational behavior of the employees in this scenario.

The theoretical contributions of the study were provided by examining the extent to which perceived organizational support can motivate positive organizational behaviors like OCB, employee engagement, and affective commitment. Furthermore, it adds to the SET by explaining how POS can enhance OCB through employee engagement and affective commitment. This study is the first to investigate the social exchange in the private 
service sector in Hungary, by incorporating variables like POS, employee engagement, affective commitment, and OCB. A path model was developed and validated in this study between POS and OCB via affective commitment and employee engagement. The results indicated that in the presence of employee engagement and affective commitment during the pandemic the direct effects from POS on OCB vanish, and mainly employee engagement is the main mediator in this relationship. The critical observation of the results revealed that at the time of the pandemic, if employees experience strong support and care from their organization, then their engagement in the work will strongly lead to their citizenship behavior. This model was validated at the time of the COVID-19 pandemic and will add value to the existing theories in terms of motivating employees to enhance their performance and commitment. Therefore, this study is a major contribution to fill a significant research gap based on the SET framework at the time of the COVID-19 pandemic. However, it is evident that pandemic has caused severe stress among employees working in the service sector, who are more in contact with people and more prone to contract the virus. Because of this reason, their performance and engagement are susceptible to reduction. This study will provide a theoretical framework to support employees in increasing their engagement, commitment, and citizenship behavior. The study will provide a strong base for future studies to apply this model in other sectors and at different time frames.

The practical implications of this study, based on our findings, suggest improving the quality of HR within the organization. Firstly, this study suggests that if managers wanted to achieve higher OCB, then they need to focus on their employees' engagement at work and their commitment to the organization. This can be done by providing higher organizational support, which is considered an important predictor of OCB in the time of COVID-19 pandemic. Consequently, when employees perceive more organizational support at the time of fear and disruption, they tend to become more engaged at work and more attached to their organization, which will lead them to have a positive citizenship behavior. Therefore, organizations and managers should make sure that they provide adequate support to their foreign employees, especially during the pandemic, because they are the most vulnerable to the impacts of the pandemic in terms of working conditions and health safety in the host country. The more support employees receive from their organizations, the more likely they will tend to make emotional attachments with their organization, and they will show more enthusiasm towards their work which will lead to higher organizational citizenship behavior.

Secondly, the results of our study revealed that both affective commitment and employee engagement are significantly associated with OCB. However, the role of employees' engagement was stronger compared to affective commitment, which emphasized that current organizational support that is perceived by foreign employees is still not enough to attain their desired level of commitment to stay in the current organization and be more emotionally attached to it. This could be the area of concern for the HR departments because they might have higher employee turnover rate inside their organizations, which at the end will increase the organizational cost if employees are not committed towards organization [135]. Although the current organizational support was achieving a higher rate of engagement between these employees, the fear of the pandemic and the uncertainty in the situation might be a reason for the employees not to be emotionally attached to their organization. Therefore, it would be recommended to the companies that operate in the service sector to focus more on their foreign employees and provide more support for them if they do not want to lose them and they need them to be more attached to their companies which can be important for the stability of the company's performance and productivity [135].

In this regard, organizations and managers should extend emotional and psychological support to the employees during the time of fear to develop their commitment for the organization. Moreover, at the time of the COVID-19 pandemic, many employees were receiving reduced salary, which might be one of the reasons for decreased commitment towards their organization. Hence, apart from emotional, social, and psychological support, 
employees may require financial support as well to boost their commitment towards their organization. As far as role of government is concerned, it is suggested that during the time of pandemic, the government can provide subsidies, grants or fiscal assistance to the businesses [136] because it will enable smooth running of their business operations. To support businesses and organizations during the pandemic, the government can provide assistance in implementing relevant measures to respond to the crisis. Furthermore, supportive policies and measures from the government will relieve business operations during the pandemic, which will help businesses to recover from the sudden disruption. This will further influence the working conditions of the employees and enhance their organizational citizenship behavior.

\section{Conclusions}

At the time of the COVID-19 pandemic, the impact of perceived organizational support is significant in enhancing organizational citizenship behavior among the foreign employees employed in the private service sector in Hungary. The current study was aimed to identify the influence of POS on OCB with the mediating effect of employee engagement and affective commitment. The results revealed that POS positively influences employee engagement, affective commitment, and OCB among foreign employees during the COVID-19 pandemic. It implies that even at the time of a pandemic, social exchange theory (SET) has been proven effective, which suggests that positive social exchange relationship reciprocates into increased attachment and commitment of employees with their organization. Although the findings of this study revealed a strong direct relationship between POS and OCB, this effect can also be mediated by employee engagement and affective commitment of the employees. The findings suggest that the significance of employees' engagement in this relationship is higher than affective commitment, which implies that employee engagement more strongly mediated the relationship between POS and OCB than affective commitment. The study also revealed that perceived organizational support is an important influencer for both affective commitment and employee engagement; the more organizational support is perceived by the employees, the more they will be committed and engaged at work. Furthermore, it was indicated that both employee engagement and affective commitment can enhance their OCB during the pandemic; however, the effect of affective commitment is low.

\section{Limitations and Future Studies}

This study has provided some valuable findings to contribute to the literature related to COVID-19. However, there are still some limitations of the study, like the study did not focus on a particular sector, rather involving employees of different service companies in general. Another limitation is that the study did not consider demographic characteristics to understand the influence of age, gender, work experience on the OCB of the employees. Hence, these characteristics of employees could give a better understanding based on demographic profiles, and future studies can incorporate them in the model. Lastly, future researchers can integrate other variables as well in their study model to provide evidence for different associations during the time of the COVID-19 pandemic.

For future studies, researchers can use and modify the proposed research model of this study by adding several other behavioral constructs. This study has focused on positive behavioral outcomes; however, there are negative behavioral outcomes that may be negatively influenced due to POS, like counterproductive behaviors; therefore, future research may focus on such variables. Moreover, it would be important to study some other variables as mediators, such as the fear of the pandemic, job insecurity, breach of the psychological contract, and organizational trust, because they might be related directly to OCB and POS. Future studies can focus as well on particular sectors of Hungary and give results based on different operational workings, for instance, the public sector, telecommunication sector, hospitality sector, tourism sector, banking sector, etc. Moreover, future 
research can make the comparison between foreign and local employees by incorporating the same or different variables of the current study.

Author Contributions: Conceptualization, A.A. and F.N.; methodology, A.A.; software, A.A.; validation, A.A. and F.N.; formal analysis, A.A..; investigation, F.N. and A.A; resources, F.N., I.R., A.A.; data curation, A.A.; writing-original draft preparation, F.N. and A.A.; writing-review and editing, R.M. and A.A.; visualization, A.A. and R.M.; supervision, I.R.; project administration, R.M., A.A.; funding acquisition, I.R. and R.M. All authors have read and agreed to the published version of the manuscript.

Funding: The APC was funded by the Hungarian University of Agriculture and Life Sciences.

Institutional Review Board Statement: Not applicable.

Informed Consent Statement: Not applicable.

Data Availability Statement: Not applicable.

Conflicts of Interest: The authors declare no conflict of interest.

\section{References}

1. Yu, J.; Park, J.; Hyun, S.S. Impacts of the COVID-19 pandemic on employees' work stress, well-being, mental health, organizational citizenship behavior, and employee-customer identification. J. Hosp. Mark. Manag. 2021, 30, 529-548. [CrossRef]

2. Li, J.-Y.; Sun, R.; Tao, W.; Lee, Y. Employee coping with organizational change in the face of a pandemic: The role of transparent internal communication. Public Relat. Rev. 2021, 47, 101984. [CrossRef]

3. Main, A.; Zhou, Q.; Ma, Y.; Luecken, L.J.; Liu, X. Relations of SARS-related stressors and coping to Chinese college students' psychological adjustment during the 2003 Beijing SARS epidemic. J. Couns. Psychol. 2011, 58, 410-423. [CrossRef]

4. Oláh, J.; Hajduová, Z.; Lacko, R.; Andrejovský, P. Quality of Life Regional Differences: Case of Self-Governing Regions of Slovakia. Sustainability 2020, 12, 2924. Available online: https://www.mdpi.com/2071-1050/12/7/2924 (accessed on 9 June 2021). [CrossRef]

5. Kaushik, M.; Guleria, N. The Impact of Pandemic COVID -19 in Workplace. Eur. J. Bus. Manag. 2020, 12, 9-18. [CrossRef]

6. Prem, R.; Ohly, S.; Kubicek, B.; Korunka, C. Thriving on challenge stressors? Exploring time pressure and learning demands as antecedents of thriving at work. J. Organ. Behav. 2017, 38, 108-123. [CrossRef] [PubMed]

7. Gunay, S.; Kurtulmuş, B.E. COVID-19 social distancing and the US service sector: What do we learn? Res. Int. Bus. Financ. 2021, 56, 101361. [CrossRef]

8. Xiang, S.; Rasool, S.; Hang, Y.; Javid, K.; Javed, T.; Artene, A.E. The Effect of COVID-19 Pandemic on Service Sector Sustainability and Growth. Front. Psychol. 2021, 12, 633597. [CrossRef]

9. Daraba, D.; Wirawan, H.; Salam, R.; Faisal, M. Working from home during the corona pandemic: Investigating the role of authentic leadership, psychological capital, and gender on employee performance. Cogent Bus. Manag. 2021, 8, 1885573. [CrossRef]

10. World Health Organization. Situation Report-101, Coronovirus disease 2019 (COVID-19). 2020. Available online: https://www. who.int/docs / default-source/coronaviruse/situation-reports /20200430-sitrep-101-covid-19.pdf?sfvrsn=2ba4e093_2 (accessed on 5 June 2021).

11. Gursoy, D.; Chi, C.G. Effects of COVID-19 pandemic on hospitality industry: Review of the current situations and a research agenda. J. Hosp. Mark. Manag. 2020, 29, 527-529. [CrossRef]

12. Wu, W.; Lee, C.-C.; Xing, W.; Ho, S.-J. The impact of the COVID-19 outbreak on Chinese-listed tourism stocks. Financ. Innov. 2021, 7, 22. [CrossRef]

13. Lakner, Z.; Kiss, A.; Merlet, I.; Oláh, J.; Máté, D.; Grabara, J.; Popp, J. Building Coalitions for a Diversified and Sustainable Tourism: Two Case Studies from Hungary. Sustainability 2018, 10, 1090. Available online: https:/ /www.mdpi.com/2071-1050/10/4/1090 (accessed on 9 June 2021). [CrossRef]

14. Hakim, M.P.; Zanetta, L.D.A.; da Cunha, D.T. Should I stay, or should I go? Consumers' perceived risk and intention to visit restaurants during the COVID-19 pandemic in Brazil. Food Res. Int. 2021, 141, 110152. [CrossRef]

15. Dube, K.; Nhamo, G.; Chikodzi, D. COVID-19 pandemic and prospects for recovery of the global aviation industry. J. Air Transp. Manag. 2021, 92, 102022. [CrossRef]

16. Loske, D. The impact of COVID-19 on transport volume and freight capacity dynamics: An empirical analysis in German food retail logistics. Transp. Res. Interdiscip. Perspect. 2020, 6, 100165. [CrossRef] [PubMed]

17. Chen, J.K.C.; Sriphon, T. Perspective on COVID-19 Pandemic Factors Impacting Organizational Leadership. Sustainability 2021, 13, 3230. Available online: https:/ / www.mdpi.com/2071-1050/13/6/3230 (accessed on 25 May 2021). [CrossRef]

18. Wong, A.K.F.; Kim, S.; Kim, J.; Han, H. How the COVID-19 pandemic affected hotel Employee stress: Employee perceptions of occupational stressors and their consequences. Int. J. Hosp. Manag. 2021, 93, 102798. [CrossRef]

19. Bulińska-Stangrecka, H.; Bagieńska, A. The Role of Employee Relations in Shaping Job Satisfaction as an Element Promoting Positive Mental Health at Work in the Era of COVID-19. Int. J. Environ. Res. Public Health 2021, 18, 1903. [CrossRef] 
20. Filimonau, V.; Derqui, B.; Matute, J. The COVID-19 pandemic and organisational commitment of senior hotel managers. Int. J. Hosp. Manag. 2020, 91, 102659. [CrossRef] [PubMed]

21. Narayanamurthy, G.; Tortorella, G. Impact of COVID-19 outbreak on employee performance-Moderating role of industry 4.0 base technologies. Int. J. Prod. Econ. 2021, 234, 108075. [CrossRef]

22. Li, B.; Fan, X.; Álvarez-Otero, S.; Sial, M.S.; Comite, U.; Cherian, J.; Vasa, L. CSR and Workplace Autonomy as Enablers of Workplace Innovation in SMEs through Employees: Extending the Boundary Conditions of Self-Determination Theory. Sustainability 2021, 13, 6104. Available online: https://www.mdpi.com/2071-1050/13/11/6104 (accessed on 9 June 2021). [CrossRef]

23. Ahmed, T.; Shahid Khan, M.; Thitivesa, D.; Siraphatthada, Y.; Phumdara, T. Impact of employees engagement and knowledge sharing on organizational performance: Study of HR challenges in COVID-19 pandemic. Hum. Syst. Manag. 2020, 39, 589-601. [CrossRef]

24. Jung, H.S.; Jung, Y.S.; Yoon, H.H. COVID-19: The effects of job insecurity on the job engagement and turnover intent of deluxe hotel employees and the moderating role of generational characteristics. Int. J. Hosp. Manag. 2021, 92, 102703. [CrossRef] [PubMed]

25. Eisenberger, R.; Malone, G.P.; Presson, W.D. Optimizing perceived organizational support to enhance employee engagement. Soc. Hum. Resour. Manag. Soc. Ind. Organ. Psychol. 2016, 2, 3-22.

26. Karkoulian, S.K.; Messarra, L. Organizational commitment recall in times of crisis. J. Int. Bus. Res. 2008, 7, 109-118.

27. Labrague, L.J.; de los Santos, J.A.A. COVID-19 anxiety among front-line nurses: Predictive role of organisational support, personal resilience and social support. J. Nurs. Manag. 2020, 28, 1653-1661. [CrossRef]

28. Chen, H.; Eyoun, K. Do mindfulness and perceived organizational support work? Fear of COVID-19 on restaurant frontline employees' job insecurity and emotional exhaustion. Int. J. Hosp. Manag. 2021, 94, 102850. [CrossRef]

29. Musenze Ibrahim, A.; Thomas, S.M.; Kalenzi, A.; Namono, R. Perceived organizational support, self-efficacy and work engagement: Testing for the interaction effects. J. Econ. Adm. Sci. 2021. ahead-of-print. [CrossRef]

30. Manuti, A.; Giancaspro, M.L.; Molino, M.; Ingusci, E.; Russo, V.; Signore, F.; Zito, M.; Cortese, C.G. "Everything Will Be Fine": A Study on the Relationship between Employees' Perception of Sustainable HRM Practices and Positive Organizational Behavior during COVID19. Sustainability 2020, 12, 10216. Available online: https:/ /www.mdpi.com/2071-1050/12/23/10216 (accessed on 23 May 2021). [CrossRef]

31. Guadagno, L. Migrants and the COVID-19 Pandemic: An Initial Analysis. International Organization for Migration (IOM). 2020. Available online: https:/ / publications.iom.int/books/mrs-no-60-migrants-and-covid-19-pandemic-initial-analysis (accessed on 5 June 2021).

32. Rudolph, C.W.; Allan, B.; Clark, M.; Hertel, G.; Hirschi, A.; Kunze, F.; Shockley, K.; Shoss, M.; Sonnentag, S.; Zacher, H.; et al. Pandemics: Implications for research and practice in industrial and organizational psychology. Ind. Organ. Psychol. 2021, 14, 1-35. [CrossRef]

33. Baksa, M.; Marciniak, R.; Nagy, D. Business Services Sector Hungary; Marciniak, R., Ránki, R., Eds.; Hungarian Service and Outsourcing Association (HOA): Budapest, Hungary, 2020.

34. Medve, F. Number of full-time international students at Hungarian universities from 2009 to 2021. Educ. Sci. 2021. Available online: https:/ / www.statista.com/statistics/1094687/hungary-international-university-students / (accessed on 25 June 2021).

35. Pongratz, N. More than 33,000 foreign students in Hungary. Bp. Bus. J. 2020. Available online: https://bbj.hu/economy/ statistics/analysis/more-than-33-000-foreign-students-in-hungary (accessed on 25 June 2021).

36. EUGO. Key facts about Hungary. Hung. Point Single Contact. 2020. Available online: http://eugo.gov.hu/key-facts-abouthungary/economy (accessed on 9 June 2021).

37. Eisenberger, R.; Huntington, R.; Hutchison, S.; Sowa, D. Perceived organizational support. J. Appl. Psychol. 1986, 71, 500. [CrossRef]

38. Jain, A.K.; Sinha, A.K. General Health in Organizations: Relative Relevance of Emotional Intelligence, Trust, and Organizational Support. Int. J. Stress Manag. 2005, 12, 257-273. [CrossRef]

39. Rhoades, L.; Eisenberger, R. Perceived organizational support: A review of the literature. J. Appl. Psychol. 2002, 87, 698. [CrossRef] [PubMed]

40. Le, P.B.; Lei, H. Determinants of innovation capability: The roles of transformational leadership, knowledge sharing and perceived organizational support. J. Knowl. Manag. 2019, 23, 527-547. [CrossRef]

41. Meyer, J.P.; Allen, N.J. Commitment in the Workplace: Theory, Research, and Application; SAGE Publications: Newbury Park, CA, USA, 1997. Available online: https:/ / books.google.hu/books?id=jn4VFpFJ2qQC (accessed on 21 May 2021).

42. Meyer, J.P.; Stanley, D.J.; Herscovitch, L.; Topolnytsky, L. Affective, continuance, and normative commitment to the organization: A meta-analysis of antecedents, correlates, and consequences. J. Vocat. Behav. 2002, 61, 20-52. [CrossRef]

43. Colakoglu, U.; Culha, O.; Atay, H. The effects of perceived organisational support on employees' affective outcomes: Evidence from the hotel industry. Tour. Hosp. Manag. 2010, 16, 125-150. [CrossRef]

44. Ko, J.-W.; Price, J.L.; Mueller, C.W. Assessment of Meyer and Allen's three-component model of organizational commitment in South Korea. J. Appl. Psychol. 1997, 82, 961-973. [CrossRef]

45. Muhammad, A.H. Perceived organizational support and organizational citizenship behavior: The case of Kuwait. Int. J. Bus. Adm. 2014, 5, 59. [CrossRef] 
46. Rameshkumar, M. Employee engagement as an antecedent of organizational commitment-A study on Indian seafaring officers. Asian J. Shipp. Logist. 2020, 36, 105-112. [CrossRef]

47. Nazir, O.; Islam, J.U. Enhancing organizational commitment and employee performance through employee engagement: An empirical check. South Asian J. Bus. Stud. 2017, 6, 98-114. [CrossRef]

48. Schaufeli, W.B.; Salanova, M.; González-romá, V.; Bakker, A.B. The Measurement of Engagement and Burnout: A Two Sample Confirmatory Factor Analytic Approach. J. Happiness Stud. 2002, 3, 71-92. [CrossRef]

49. Robinson, D.; Perryman, S.; Hayday, S. The Drivers of Employee Engagement; Institute for Employment Studies: Brighton, UK, 2004.

50. Downey, S.N.; van der Werff, L.; Thomas, K.M.; Plaut, V.C. The role of diversity practices and inclusion in promoting trust and employee engagement. J. Appl. Soc. Psychol. 2015, 45, 35-44. [CrossRef]

51. Alshaabani, A.; Naz, F.; Rudnák, I. Impact of Green Human Resources Practices on Green Work Engagement in the Renewable Energy Departments. Int. Bus. Res. 2021, 14, 44-58. [CrossRef]

52. Alshaabani, A.; Oláh, J.; Popp, J.; Zaien, S. Impact of Distributive Justice on The Trust Climate Among Middle Eastern Employees. Pol. J. Manag. Stud. 2020, 21, 34-47. [CrossRef]

53. Saks, A.M. Antecedents and consequences of employee engagement. J. Manag. Psychol. 2006, 21, 600-619. [CrossRef]

54. Ghosh, P.; Rai, A.; Sinha, A. Organizational justice and employee engagement. Pers. Rev. 2014, 34, 628-652. [CrossRef]

55. Biswas, S.; Bhatnagar, J. Mediator Analysis of Employee Engagement: Role of Perceived Organizational Support, P-O Fit, Organizational Commitment and Job Satisfaction. Vikalpa 2013, 38, 27-40. [CrossRef]

56. Macey, W.H.; Schneider, B. The Meaning of Employee Engagement. Ind. Organ. Psychol. 2008, 1, 3-30. [CrossRef]

57. Einarsen, S.; Skogstad, A.; Rørvik, E.; Lande, Å.B.; Nielsen, M.B. Climate for conflict management, exposure to workplace bullying and work engagement: A moderated mediation analysis. Int. J. Hum. Resour. Manag. 2018, 29, 549-570. [CrossRef]

58. Chandani, A.; Mehta, M.; Mall, A.; Khokhar, V. Employee Engagement: A Review Paper on Factors Afecting Employee Engagement. Indian J. Sci. Technol. 2016, 9, 1-7. [CrossRef]

59. Imran, M.Y.; Elahi, N.S.; Abid, G.; Ashfaq, F.; Ilyas, S. Impact of Perceived Organizational Support on Work Engagement: Mediating Mechanism of Thriving and Flourishing. J. Open Innov. Technol. Mark. Complex. 2020, 6, 82. [CrossRef]

60. Jehanzeb, K. Does perceived organizational support and employee development influence organizational citizenship behavior? Eur. J. Train. Dev. 2020, 44, 637-657. [CrossRef]

61. Nisha Chanana, S. Employee engagement practices during COVID-19 lockdown. J. Public Aff. 2020, e2508. [CrossRef]

62. Bies, R. Organizational Citizenship Behavior: The Good Soldier Syndrome. J. Acad. Manag. Rev. 1989, 14, 294-297. Available online: www.jstor.org/stable/258426 (accessed on 8 June 2021). [CrossRef]

63. Organ, D.W. Organizational citizenship behavior: It's construct clean-up time. Hum. Perform. 1997, 10, 85-97. [CrossRef]

64. Jahangir, N.; Akbar, M.M.; Haq, M. Organizational Citizenship Behavior: Its Nature and Antecedents. BRAC Univ. J. 2004, 1, 75-85. [CrossRef]

65. Bienstock, C.C.; DeMoranville, C.W.; Smith, R.K. Organizational citizenship behavior and service quality. J. Serv. Mark. 2003, 17, 357-378. [CrossRef]

66. Andriyanti, N.P.V.; Supartha, I.W.G. Effect of perceived organizational support on organizational citizenship behavior with work satisfaction as mediating variables. Am. J. Humanit. Soc. Sci. Res. (AJHSSR) 2021, 1, 46-55.

67. Foote, D.A.; Tang, T.L. Job satisfaction and organizational citizenship behavior (OCB). Manag. Decis. 2008, 46, 933-947. [CrossRef]

68. Jiao, C.; Richards, D.A.; Zhang, K. Leadership and Organizational Citizenship Behavior: OCB-Specific Meanings as Mediators. J. Bus. Psychol. 2011, 26, 11-25. [CrossRef]

69. Suliman, A.; al Obaidli, H. Leadership and organizational citizenship behavior (OCB) in the financial service sector. Asia-Pac. J. Bus. Adm. 2013, 5, 115-134. [CrossRef]

70. Ifta Firdausa, N.; Ema, N. The influence of distributive justice, job satisfaction and affective commitment to organizational citizenship behavior. Rev. Produção E Desenvolv. 2020, 6. [CrossRef]

71. Kartika, E.W.; Pienata, C. The Role of Organizational Commitment on Organizational Citizenship Behavior in Hotel Industry. J. Manaj. 2020, 24, 373-391.

72. Atrizka, D.; Lubis, H.; Simanjuntak, C.W.; Pratama, I. Ensuring Better Affective Commitment and Organizational Citizenship Behavior through Talent Management and Psychological Contract Fulfillment: An Empirical Study of Indonesia Pharmaceutical Sector. Syst. Rev. Pharm. 2020, 11, 545-553. [CrossRef]

73. Ariani, D.W. The relationship between employee engagement, organizational citizenship behavior, and counterproductive work behavior. Int. J. Bus. Adm. 2013, 4, 46.

74. Kahn, W.A. Psychological conditions of personal engagement and disengagement at work. Acad. Manag. J. 1990, 33, 692-724. [CrossRef]

75. Byrne, Z.S.; Hochwarter, W.A. Perceived organizational support and performance: Relationships across levels of organizational cynicism. J. Manag. Psychol. 2008, 23, 54-72. [CrossRef]

76. Yang, S.; Huang, H.; Qiu, T.; Tian, F.; Gu, Z.; Gao, X.; Wu, H. Psychological Capital Mediates the Association Between Perceived Organizational Support and Work Engagement Among Chinese Doctors. Front. Public Health 2020, 8, 149. [CrossRef]

77. Rahman, A.; Björk, P.; Ravald, A. Exploring the effects of service provider's organizational support and empowerment on employee engagement and well-being. Cogent Bus. Manag. 2020, 7, 1767329. [CrossRef] 
78. Caesens, G.; Stinglhamber, F. The relationship between perceived organizational support and work engagement: The role of self-efficacy and its outcomes. Eur. Rev. Appl. Psychol. 2014, 64, 259-267. [CrossRef]

79. Blau, P.M. Social exchange theory. Int. Encycl. Soc. Sci. 1964, 3, 62.

80. Lee, J.; Peccei, R. Perceived organizational support and affective commitment: The mediating role of organization-based self-esteem in the context of job insecurity. J. Organ. Behav. Int. J. Ind. Occup. Organ. Psychol. Behav. 2007, 28, 661-685. [CrossRef]

81. Cropanzano, R.; Mitchell, M.S. Social exchange theory: An interdisciplinary review. J. Manag. 2005, 31, 874-900. [CrossRef]

82. Walumbwa, F.O.; Cropanzano, R.; Goldman, B.M. How Leader-Member Exchange Influences Effective Work Behaviors: Social Exchange and Internal-External Efficacy Perspectives. Pers. Psychol. 2011, 64, 739-770. [CrossRef]

83. Garcia, P.R.J.M.; Amarnani, R.K.; Bordia, P.; Restubog, S.L.D. When support is unwanted: The role of psychological contract type and perceived organizational support in predicting bridge employment intentions. J. Vocat. Behav. 2021, 125, 103525. [CrossRef]

84. Hoa, N.D.; Ngan, P.T.; Quang, N.M.; Thanh, V.B.; Quyen, H.V. An empirical study of perceived organizational support and affective commitment in the logistics industry. J. Asian Financ. Econ. Bus. Manag. Econ. Eng. 2020, 7, 589-598. [CrossRef]

85. Ullah, I.; Elahi, N.S.; Abid, G.; Butt, M.U. The impact of perceived organizational support and proactive personality on affective commitment: Mediating role of prosocial motivation. Bus. Manag. Econ. Eng. 2020, 18, 183-205. [CrossRef]

86. Wayne, S.J.; Shore, L.M.; Bommer, W.H.; Tetrick, L.E. The role of fair treatment and rewards in perceptions of organizational support and leader-member exchange. J. Appl. Psychol. 2002, 87, 590-598. [CrossRef]

87. Azim, A.M.M.; Dora, M.T. Perceived organizational support and organizational citizenship behavior: The mediating role of psychological capital. J. Hum. Cap. Dev. 2016, 9, 99-118.

88. Organ, D.W.; Paine, J.B. A new kind of performance for industrial and organizational psychology: Recent contributions to the study of organizational citizenship behavior. Int. Rev. Ind. Organ. Psychol. 1999, 14, 337-368.

89. Spector, P.E.; Che, X.X. Re-examining citizenship: How the control of measurement artifacts affects observed relationships of organizational citizenship behavior and organizational variables. Hum. Perform. 2014, 27, 165-182. [CrossRef]

90. Konovsky, M.A.; Pugh, S.D. Citizenship behavior and social exchange. Acad. Manag. J. 1994, 37, 656-669.

91. Settoon, R.P.; Bennett, N.; Liden, R.C. Social exchange in organizations: Perceived organizational support, leader-member exchange, and employee reciprocity. Acad. Manag. J. 1996, 81, 219.

92. Ali, F.H.; Rizavi, S.S.; Ahmed, I.; Rasheed, M. Effects of perceived organizational support on organizational citizenship behaviorSequential mediation by well-being and work engagement. J. Punjab Univ. Hist. Soc. 2018, 31, 111-131.

93. Wayne, S.J.; Shore, L.M.; Liden, R.C. Perceived organizational support and leader-member exchange: A social exchange perspective. Acad. Manag. J. 1997, 40, 82-111.

94. Ali, N. Effects of Perceived Organizational Support and Leader-Member Exchange on Organizational Citizenship Behavior. J. Manag. Sci. 2009, 3, 53-56.

95. Islam, T.; Khan, S.u.R.; Ahmad, U.N.U.; Ahmed, I. Exploring the Relationship Between POS, OLC, Job Satisfaction and OCB. Procedia-Soc. Behav. Sci. 2014, 114, 164-169. [CrossRef]

96. Bartkowiak, G.; Krugiełka, A.; Dachowski, R.; Gałek, K.; Kostrzewa-Demczuk, P. Attitudes of Polish Entrepreneurs towards 65+ Knowledge Workers in the Context of Their Pro-Social Attitude and Organizational Citizenship Behavior. Sustainability 2020, 12, 5294. Available online: https: / / www.mdpi.com/2071-1050/12/13/5294 (accessed on 26 June 2021). [CrossRef]

97. Thakre, N.; Mathew, P. Psychological empowerment, work engagement, and organizational citizenship behavior among Indian service-sector employees. GBOE 2020, 39, 45-52. [CrossRef]

98. Sulea, C.; Virga, D.; Maricutoiu, L.P.; Schaufeli, W.; Dumitru, C.Z.; Sava, F.A. Work engagement as mediator between job characteristics and positive and negative extra-role behaviors. Career Dev. Int. 2012, 17, 188-207. [CrossRef]

99. Jin, M.H.; McDonald, B. Understanding Employee Engagement in the Public Sector: The Role of Immediate Supervisor, Perceived Organizational Support, and Learning Opportunities. Am. Rev. Public Adm. 2016, 47, 881-897. [CrossRef]

100. Saradha, H.; Patrick, H.A. Employee engagement in relation to organizational citizenship behavior in information technology organizations. J. Mark. Manag. 2011, 2, 74-90.

101. Obedgiu, V.; Bagire, V.; Mafabi, S. Examination of organizational commitment and organizational citizenship behaviour among local government civil servants in Uganda. J. Manag. Dev. 2017, 36, 1304-1316. [CrossRef]

102. Feldman, D.C. The Dilbert Syndrome: How Employee Cynicism about Ineffective Management is Changing the Nature of Careers in Organizations. Am. Behav. Sci. 2000, 43, 1286-1300. [CrossRef]

103. Wang, X.; Ma, L.; Zhang, M. Transformational leadership and agency workers' organizational commitment: The mediating effect of organizational justice and job characteristics. Soc. Behav. Personal. Int. J. 2014, 42, 25-36. [CrossRef]

104. Park, J.-Y.; Hight, S.K.; Bufquin, D.; de Souza Meira, J.V.; Back, R.M. An examination of restaurant employees' work-life outlook: The influence of support systems during COVID-19. Int. J. Hosp. Manag. 2021, 97, 102992. [CrossRef]

105. Masterson, S.S.; Lewis, K.; Goldman, B.M.; Taylor, M.S. Integrating justice and social exchange: The differing effects of fair procedures and treatment on work relationships. Acad. Manag. J. 2000, 43, 738-748.

106. Shams, M.S.; Niazi, M.M.; Asim, F. The Relationship Between Perceived Organizational Support, Employee Engagement, and Organizational Citizenship Behavior: Application of PLS-SEM Approach. Kardan J. Econ. Manag. Sci. 2020, 3, 35-55.

107. Karatepe, O.M. High-performance work practices and hotel employee performance: The mediation of work engagement. Int. J. Hosp. Manag. 2013, 32, 132-140. [CrossRef] 
108. Piercy, N.F.; Cravens, D.W.; Lane, N.; Vorhies, D.W. Driving organizational citizenship behaviors and salesperson in-role behavior performance: The role of management control and perceived organizational support. J. Acad. Mark. Sci. 2006, 34, $244-262$. [CrossRef]

109. Valeau, P.J.; Paillé, P. The management of professional employees: Linking progressive HRM practices, cognitive orientations and organizational citizenship behavior. Int. J. Hum. Resour. Manag. 2019, 30, 2705-2731. [CrossRef]

110. Liu, Y. Perceived organizational support and expatriate organizational citizenship behavior. Pers. Rev. 2009, 38, 307-319. [CrossRef]

111. Baruch, Y.; Holtom, B.C. Survey response rate levels and trends in organizational research. Hum. Relat. 2008, 61, 1139-1160. [CrossRef]

112. Allen, N.J.; Meyer, J.P. The measurement and antecedents of affective, continuance and normative commitment to the organization. J. Occup. Psychol. 1990, 63, 1-18. [CrossRef]

113. Smith, A.C.; Organ, D.W.; Near, J.P. Organizational citizenship behavior: Its nature and antecedents. J. Appl. Psychol. 1983, 68, 653. [CrossRef]

114. Becker, T.E.; Randall, D.M. Validation of a Measure of Organizational Citizenship Behavior Against an Objective Behavioral Criterion. Educ. Psychol. Meas. 1994, 54, 160-167. [CrossRef]

115. Podsakoff, P.M.; MacKenzie, S.B.; Lee, J.Y.; Podsakoff, N.P. Common method biases in behavioral research: A critical review of the literature and recommended remedies. J. Appl. Psychol. 2003, 88, 879-903. [CrossRef] [PubMed]

116. Burton-Jones, A. Minimizing Method Bias through Programmatic Research. MIS Q. 2009, 33, 445-471. [CrossRef]

117. Podsakoff, P.M.; MacKenzie, S.B.; Podsakoff, N.P. Sources of Method Bias in Social Science Research and Recommendations on How to Control It. Annu. Rev. Psychol. 2012, 63, 539-569. [CrossRef]

118. Sekaran, U.; Bougie, R. Research Methods For Business: A Skill Building Approach; Wiley: West Sussex, UK, 2016. Available online: https:/ /books.google.hu/books?id=Ko6bCgAAQBAJ (accessed on 5 May 2021).

119. Kaiser, H.F. An index of factorial simplicity. Psychometrika 1974, 39, 31-36. [CrossRef]

120. Kline, P. An Easy Guide to Factor Analysis; Routledge: London, UK, 2014.

121. Hair, J.F.; Sarstedt, M.; Ringle, C.M.; Gudergan, S.P. Advanced Issues in Partial Least Squares Structural Equation Modeling; SAGE Publications: Los Angeles, USA, 2017. Available online: https:// books.google.hu/books?id=5wmXDgAAQBAJ (accessed on 8 May 2021).

122. Chin, W.W. Commentary: Issues and Opinion on Structural Equation Modeling. MIS Q. 1998, 22, vii-xvi. Available online: http:/ / www.jstor.org/stable/249674 (accessed on 4 May 2021).

123. Bagozzi, R.P.; Yi, Y.; Phillips, L.W. Assessing Construct Validity in Organizational Research. Adm. Sci. Q. 1991, 36, 421-458. [CrossRef]

124. Hair, J.F.; Black, W.C.; Babin, B.J. Multivariate Data Analysis: A Global Perspective; Pearson Education: Upper Saddle River, NJ, USA; London, UK, 2010. Available online: https:/ / books.google.hu/books?id=SLRPLgAACAAJ (accessed on 5 May 2021).

125. Hu, L.t.; Bentler, P.M. Cutoff criteria for fit indexes in covariance structure analysis: Conventional criteria versus new alternatives. Struct. Equ. Model. A Multidiscip. J. 1999, 6, 1-55. [CrossRef]

126. Hooper, D.; Coughlan, J.; Mullen, M. Structural Equation Modelling: Guidelines for Determining Model Fit. Electron. J. Bus. Res. Methods 2008, 6, 53-60. [CrossRef]

127. Kaplan, D. Structural Equation Modeling. In International Encyclopedia of the Social E Behavioral Science; Smelser, N.J., Baltes, P.B., Eds.; Oxford: Pergamon, Turkey, 2001; pp. 15215-15222.

128. Hair, J.; Anderson, R.; Black, B.; Babin, B. Multivariate Data Analysis; Pearson Education: Harlow, UK, 2016. Available online: https:/ /books.google.hu/books?id=LKOSAgAAQBAJ (accessed on 5 May 2021).

129. Dai, K.; Qin, X. Perceived Organizational Support and Employee Engagement: Based on the Research of Organizational Identification and Organizational Justice. Open J. Soc. Sci. 2016, 4, 46-57. [CrossRef]

130. Aubé, C.; Rousseau, V.; Morin, E.M. Perceived organizational support and organizational commitment. J. Manag. Psychol. 2007, 22, 479-495. [CrossRef]

131. Sugianingrat, I.A.; Widyawati, S.R.; da Costa, C.A.; Ximenes, M.; Piedade, S.D.; Sarmawa, W.G. The employee engagement and OCB as mediating on employee performance. Int. J. Product. Manag. 2019, 68, 319-339. [CrossRef]

132. Zhang, H.; Zhao, Y.; Zou, P.; Lin, S.; Mu, S.; Deng, Q.; Du, C.; Zhou, G.; Wu, J.; Gan, L. Explaining Organizational Citizenship Behavior Among Chinese Nurses Combating COVID-19. Risk Manag. Healthc Policy 2021, 14, 979-986. [CrossRef]

133. Hu, J.; He, W.; Zhou, K. The mind, the heart, and the leader in times of crisis: How and when COVID-19-triggered mortality salience relates to state anxiety, job engagement, and prosocial behavior. J. Appl. Psychol. 2020, 105, 1218-1233. [CrossRef]

134. Lee, T.-C.; Yao-Ping Peng, M.; Wang, L.; Hung, H.K.; Jong, D. Factors Influencing Employees' Subjective Wellbeing and Job Performance During the COVID-19 Global Pandemic: The Perspective of Social Cognitive Career Theory. Front. Psychol. 2021, 12. [CrossRef]

135. Vandenberghe, C.; Bentein, K.; Stinglhamber, F. Affective commitment to the organization, supervisor, and work group: Antecedents and outcomes. J. Vocat. Behav. 2004, 64, 47-71. [CrossRef]

136. Salem, I.E.; Elbaz, A.M.; Elkhwesky, Z.; Ghazi, K.M. The COVID-19 pandemic: The mitigating role of government and hotel support of hotel employees in Egypt. Tour. Manag. 2021, 85, 104305. [CrossRef] 